\title{
Ecological and growth patterns of the longsnout seahorse Hippocampus reidi inferred by mark-recapture techniques in a tropical estuary
}

\author{
Roberto Schwarz, Junior ${ }^{1}$, Ana Cristina Novelino Penna Franco ${ }^{2}$, Adauto de Souza Ribeiro ${ }^{2}$, Marcel \\ Andrade Martins ${ }^{1}$, Marcelo Soeth ${ }^{3,4}$, Olímpio Rafael Cardoso ${ }^{3,5^{*}}$ \& Henry Louis Spach \& $^{3,4,5}$ \\ ${ }^{1}$ Universidade Federal de Sergipe, Departamento de Engenharia de Pesca e Aquicultura, Av. Marechal Rondon, \\ $s / n, J d$. Rosa Elze, 49100-000, São Cristóvão, SE, Brasil. \\ ${ }^{2}$ Universidade Federal de Sergipe, Programa de Pós-Graduação em Desenvolvimento e Meio Ambiente, Av. \\ Marechal Rondon, s/n, Jd. Rosa Elze, 49100-000, São Cristóvão, SE, Brasil. \\ ${ }^{3}$ Universidade Federal do Paraná, Centro de Estudos do Mar, Laboratório de Ecologia de Peixes, P.O. Box 61, \\ 83255-976, Pontal do Paraná, PR, Brasil. \\ ${ }^{4}$ Universidade Federal do Paraná, Programa de Pós-Graduação em Sistemas Costeiros e Oceânicos, P.O. Box \\ 61, 83255-976, Pontal do Paraná, PR, Brasil. \\ ${ }^{5}$ Universidade Federal do Paraná, Centro Politécnico, Programa de Pós-Graduação em Zoologia, Jardim das \\ Américas, P.O. 19020, 81531-980, Curitiba, PR, Brasil. \\ *Corresponding author: Olímpio Rafael Cardoso, e-mail: rafael.bioufrgs@gmail.com
}

SCHWARZ JUNIOR, R., FRANCO, A.C.N.P., RIBEIRO, A.S., MARTINS, M.A, SOETH, M., CARDOSO, O.R., SPACH, H.L. Ecological and Growth patterns of the longsnout seahorse Hippocampus reidi inferred by mark-recapture techniques in a tropical estuary. Biota Neotropica 21(2): e20201130. https://doi.org/10.1590/1676-0611-BN-2020-1130

\begin{abstract}
The population structure of the longsnout seahorse Hippocampus reidi (Ginsburg 1933) was evaluated in an estuarine system in northeastern Brazil. A total of 425 captures were performed in the Vaza-Barris estuary and 232 individuals were marked with Visible Implant Fluorescent Elastomers. The population was estimated to be composed of 428 fish. The von Bertalanffy growth curve shows a steeper growth during the first months of life, up to about 17 months, and stabilization after $16 \mathrm{~cm}$ and 27 months of age. The hereby study indicates that the Vaza-Barris estuary is home to resident populations of longsnout seahorses. Moreover, these populations use mangrove roots as the main substrate for attachment and present well-defined ecological characteristics, such as habitat fidelity and highly structured social organization.
\end{abstract}

Keywords: Fishes; population dynamics; life history; fluorescent elastomer.

\section{Padrões ecológicos e de crescimento do cavalo-marinho Hippocampus reidi inferidos por técnicas de recaptura em um estuário tropical}

\footnotetext{
Resumo: A estrutura populacional do cavalo-marinho Hippocampus reidi (Ginsburg 1933) foi avaliada em um sistema estuarino no nordeste do Brasil. Um total de 425 capturas foram realizadas no estuário de Vaza-Barris e 232 indivíduos foram marcados com Elastômeros Fluorescentes de Implante Visível. A população foi estimada em 428 peixes. A curva de crescimento de von Bertalanffy mostra um crescimento mais acentuado durante os primeiros meses de vida, até cerca de 17 meses, e estabilização após os $16 \mathrm{~cm}$ e 27 meses de idade. O presente estudo indica que o estuário Vaza-Barris é o lar de populações residentes de cavalos-marinhos de focinho comprido. Além disso, essas populações utilizam raízes de mangue como principal substrato de fixação e apresentam características ecológicas bem definidas, como fidelidade de habitat e organização social altamente estruturada.
}

Palavras-chave: Peixes; dinâmica populacional; historia de vida; elastômero fluorescente. 


\section{Introduction}

Human activity in the marine environment has caused a decline in the number of species worldwide. Overfishing, pollution, bioinvasions, climate change, and habitat loss pose serious threats to marine species worldwide (Lotze et al. 2006; Worm et al. 2006; Hughes et al. 2009). According to the International Union for Conservation of Nature red list (IUCN), from 17,228 fish species evaluated in 2019, a total of 2,341 are considered vulnerable, including 11 species of the family Syngnathidae (IUCN 2019). The three species of the genus Hippocampus in Brazil $(H$. erectus, $H$. patagonicus, and $H$. reidi) are also considered vulnerable in the list of Brazilian fauna species threatened with extinction (Portarias MMA $n^{\circ} 444 / 2014$ e $n^{\circ} 445 / 2014$ ). Hippocampus reidi (Ginsburg 1933), has been included in Appendix II of the National List of Species of Aquatic Invertebrates and Fish Overexploited or Threatened by Overexploitation since 2004, in accordance with Normative Instruction 05 (dated May 21, 2004) of the Brazilian Ministry of the Environment. Currently, this species is classified as near-threatened by the IUCN (Oliveira \& Pollom 2017).

Hippocampus species are usually monogamous and form couples in nature (Lourie et al. 1999), with all having vital parental care (Foster \& Vincent 2004). In addition, studies have shown that seahorses have high site fidelity (Perante et al. 2002), highly structured social behavior (Vincent \& Sadler 1995), sparse distribution, low mobility, and low fecundity (Foster \& Vincent 2004).

Despite being highly exploited, seahorses are not included in the official records of fisheries statistics in Brazil, and there are few papers aimed at understanding seahorse populations in their natural habitats ( Rosa et al. 2007, Curtis et al. 2017, Siqueira et al. 2017) which ultimately helps to assess their conservation status. The seahorse Hippocampus reidi is directly exposed to anthropogenic threats along the Brazilian coast, but the species still figures as Data Deficient (DD). The lack of information has made it difficult to predict the real susceptibility of populations. On the other hand, some methodological tools have been recently developed and improved so that more reliable population monitoring data are generated. Within the scope of tools, the marking procedure with Visible Implant Fluorescent Elastomer (VIE) is noteworthy. It was developed to provide externally visible internal marks for fish and other aquatic animals. In view of the short application time biocompatible composition of the merker this type of marking is suitable for use on seahorses (Curtis 2006 ). As demonstrated by Woods \& Martin-Smith (2004), implanting elastomer tags in seahorses does not alter their behaviour or growth, and eventhough these tags are considered permanent, they are unlikely to affect crypsis, as animals havebeen observed alive 4 years after initial tagging (Harasti et al. 2012). As these fish have low mobility, such markings with elastomer implants provide good responses from an ecological point of view, making it possible to monitor marked individuals in their natural environment.

The present study was developed to demonstrate the applicability of this marking-recapture method to determine the population structure and growth patterns of seahorses and to estimate population parameters in order to assess their conservation status.

\section{Materials and Methods}

The study region comprises the Vaza-Barris estuary, which is located to the south of the Aracaju city Sergipe, Brazil, within the Tropical Western Atlantic (Figure 1). This estuary is surrounded by several cities, including São Cristóvão, Pedreira, Colégio, Itaporanga d'Ajuda, and Aracaju. It is a tourist place under high real estate pressure due to the expansion of the cities. In this estuary, there are also several sources of anthropogenic contamination, such as the discharge of untreated urban sewage and effluents from agricultural, livestock, and shrimp farming activities (Vasco et al. 2010; Lima \& Silva 2014). The samples were conducted at three sites, known as Viral Stream $\left(11^{\circ} 07^{\prime} 33.9^{\prime \prime}\right.$ S, 37 $\left.09^{\prime} 20.7^{\prime \prime} \mathrm{W}\right)$, Caruara Stream $\left(11^{\circ} 07^{\prime} 05.7^{\prime \prime} \mathrm{S}, 37^{\circ} 09^{\prime} 16.6^{\prime \prime} \mathrm{W}\right)$, and Baleia Stream $\left(11^{\circ} 07^{\prime} 23.9^{\prime \prime} \mathrm{S}\right.$, $\left.37^{\circ} 10^{\prime} 22.3^{\prime \prime} \mathrm{W}\right)$. Samples were collected monthly between September 2013 and May 2015, comprising twenty-one field observations. The number of transects varied among the sampling sites because the extent of the vegetated margin was different between them. So, three transects were carried out monthly in the Baleia Stream (62 transects in total), one transect in the Viral Stream (21 transects in total), and four transects in the Caruara Stream (84 transects in total). Transects of $50 \mathrm{~m}$ length were previously marked with the help of a measuring tape positioned near the bank. For monitoring purposes, the sampling sites were georeferenced with a GPS and transects were always carried out in the same places. To determine the geographical coordinates of each fish, a standard GPS was used.

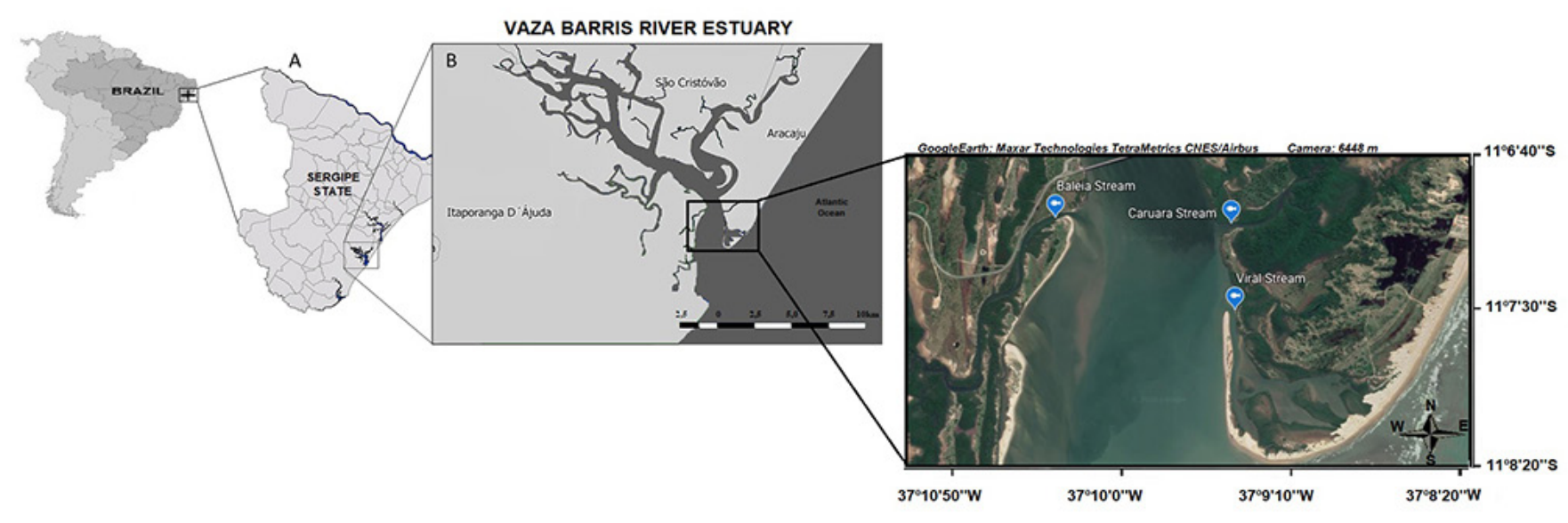

Figure 1. Lower portion of the Vaza-Barris estuary, Sergipe State, Brazil, indicating collection sites. 
Markings started in January 2014 after team training. The training was carried out in the Laboratório de Ictiologia Estuarina e Marinha (Universidade Federal de Sergipe) using captive seahorses, for safe and effective application of the method in field (Capture and Handling Permition Nr. 38844-2 - SISBIO/ICMBio/MMA).

At each sampling site, an observer in the water visually searched for seahorses near the margins, especially among vegetation roots, mostly of Rhizophora mangle (red mangrove). The average depth at the margins was approximately 1.5 meters and the width of the transect was approximately 1 meter. With visibility covering the entire water column, it was possible to view the fish even when they were fixed close to the bottom, with no need for snorkel or diving equipment for underwater viewing. The fish were caught manually, without the need for collection equipment.

Samples were preferably performed at low spring tides, when mangrove roots allowing better detection of the fish.

For each individual, the following data were recorded in the field form: location (GPS coordinates); sex; fish height (stretching the tail), tail and head length (in $\mathrm{cm}$ ); width (greater lateral size, from the abdomen to the back of the fish, in cm); attachment substrate; and behavior (standing or swimming). The sizes were measured using a caliper, and measurements accuracy was $1 \mathrm{~mm}$ (Figure 2). Also, the formation and quantification of groups and probable couples were recorded. Regarding sex, were considered the following categories: (I) Undetermined, individuals with no visible sexual differentiation; (M) Male, presence of brood pouch, prominent or not; and (F) Female, absence of brood pouch and presence of evident egg-laying organ (Lourie et al. 2004).

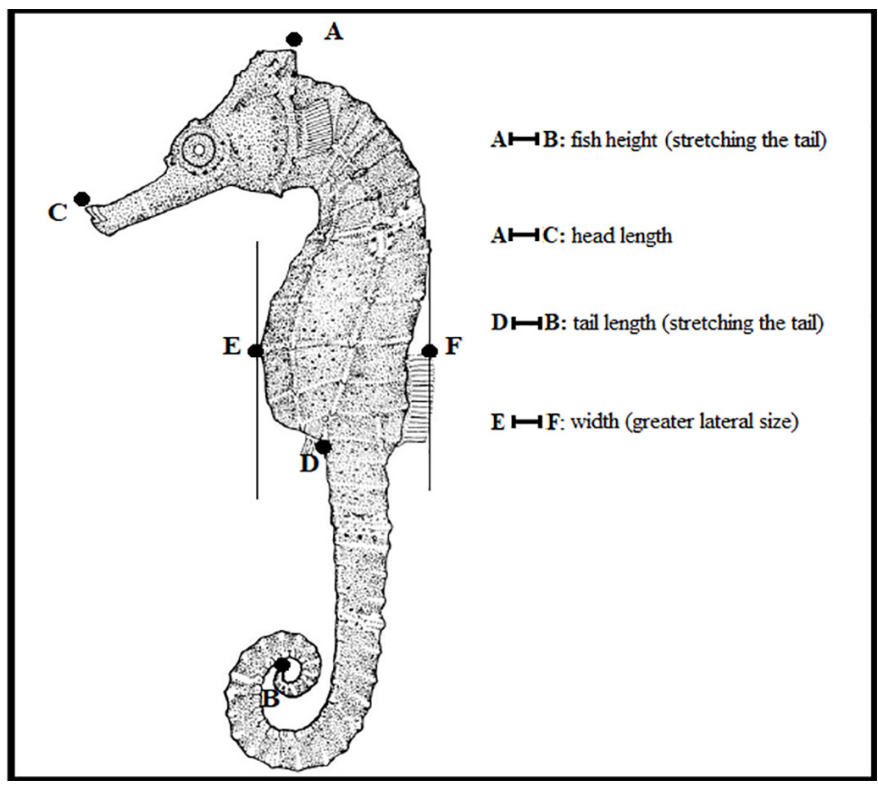

Figure 2. Measures taken in $H$. reidi captured specimens.

In order to mark individuals, the biocompatible Fluorescent Elastomer (Northwest Marine Technology Inc.) implant was preferably injected into translucent fish tissues between the bony rings of the tail. Before proceeding with the in-situ marking, five specimens were held captive and monitored in the laboratory for the detection of possible responses to the implant (especially susceptibility to infection after application), thereby ensuring the effectiveness of the method.
An alphanumeric coding was created, which, together with the specific color of the elastomer, allowed a rapid detection of the code related to the marked individual. For example, the code $7 \mathrm{r} 8 \mathrm{y} 9$ indicates that the recaptured individual has a red marking between the seventh and eighth tail rings and a yellow marking between the eighth and ninth tail rings (Figure 3 ). The bone rings were counted starting from the anus of the fish, taking care (particularly in males) to not reach the brood pouch, thus avoiding lesions to this structure. In these cases, the implant was placed after the seventh or eighth bone ring of the tail. Considering the markings made in distinct body places and with different colors, the identification codes of the specimens were created and recorded in the field form. In this study, the smallest marked specimen had a body height of $6 \mathrm{~cm}$. Individuals smaller than $6 \mathrm{~cm}$ were not marked in order to avoid injuries to the tail bone structure and physical damage to the animal due to their small size and fragility.

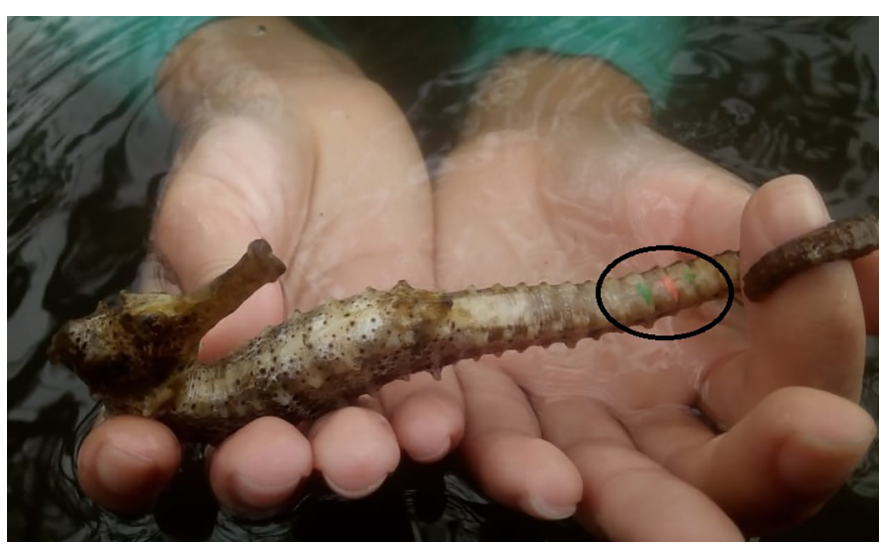

Figure 3. Seahorse marked using the visible elastomer implant method. Recaptured fish with green and pink markings on the tail.

The injections containing the markers were prepared in the field at the time of collection and preserved in ice to avoid curing and consequent hardening of the marker. A combination of two colors per field phase was used. Individuals monitored in the field were quickly returned to their habitat, taking the utmost care during handling. In the case of recapture, the data were compared with previous observations to determine patterns of occurrence, group formation, growth, and reproduction.

The obtained data were processed in Excel and Statistica 10 (Stat Soft $\left.{ }^{\circledR}\right)$. Excel was used for the preliminary organization of the data and for the descriptive analysis of growth and fidelity to the partner. Statistica 10 (StatSoft, Corp.) was used to perform descriptive statistical analyses, frequency tables, graphs, and analytical procedures of data management, as well as analyzing variables. Results are presented as mean and SD.

For density calculation for each transect, the observations per fifty-meter transect performed at each collection site were used. In order to estimate population density, the Capture Calendar, which was popularized by Krebs (1966) as the Minimum Number Known to be Alive (NMA) and considers the catch history $\left(1^{\text {st }}\right.$ catch + recaptures $)$ to evaluate the population density, was used. According to this postulate, the history of catches of each individual is analyzed over a series of successive events (i) of capture. The estimate of $\mathrm{Ni}$ (in this case $\mathrm{N}$ represents the total number of individuals in the population) is given by the number of individuals captured at i plus the number of individuals not seen at $i$ but captured before and after $i$. There are a number of 
methods for estimating $\mathrm{Ni}$ in a population closed by removal, of which Hayne's (modified from Leslie's) is one of the best currently known (Brower \& Zar 1984, Le Cheminant 2000). In this analysis, the number of previously caught and marked animals is virtually removed, and a linear regression is performed between the number of animals captured each day (y-axis) and the number of previously captured animals (x-axis). The point where the line intercepts the abscissa axis provides the $\mathrm{Ni}$, and it can be estimated by regression analysis without the need to remove all the individuals. The assumptions for Hayne's postulate, which are the condition of closed population and equal catchability among individuals, have been shown to be applicable to this study as it was observed that the populations of seahorses behave this way due to their ecological characteristics.

Applying this premise to the data, considering the Y-axis composed of the number of new individuals captured at each field phase and the $\mathrm{X}$-axis corresponding to the cumulative total of individuals was observed. Thus, the linear regression equation is obtained, and when the value 0 is applied to $\mathrm{Y}$, the projection of $\mathrm{X}$ is determined. According to Hayne's postulate, this value corresponds to the estimated total number of seahorses for each area studied. The estimation of the population size, generated from the method of calculation of density of Capture-MarkRecapture, estimated the number of seahorses for each area studied.

The size-at-time data were also adjusted to the Von Bertalanffy growth model (VBGM), which expresses the height $(\mathrm{H})$ as a function of the age $(\mathrm{t})$ of the fish, through the equation: $H(\mathrm{t})=H_{\infty} *[1-\exp$ $\left.\left(-\mathrm{K}^{*}(\mathrm{t}-\mathrm{t} 0)\right)\right]$. The asymptotic height $\left(\mathrm{H}_{\infty}\right)$ was calculated by the observed maximum height $\left(\mathrm{H}_{\max }\right)$ following the Taylor (1958) equation, where $\mathrm{H}_{\infty}=\mathrm{H}_{\max } / 0.95$. After the calculation of $\mathrm{H}_{\infty}$, the growth constant $\mathrm{K}$ was calculated by the method of Munro (1982), in which $\mathrm{K}=\left[\log \left(\mathrm{H}_{\infty}-\mathrm{Hi}\right)\right.$ $\left.-\log \left(\mathrm{H}_{\infty}-\mathrm{Hf}\right) /(\mathrm{tf}-\mathrm{ti})\right]$, being Hi the fish height observed at the time of its capture and Hf the height of the same at the time of its recapture. The variable tf - ti represents the temporal variation between the two capture moments. For VBGM, considering that $t_{0}$ is the theoretical age (years) at which the height is zero, a value of $t_{0}=-0.04$ was used. This value represents the period of incubation of the brood that, despite being born with an average height of $0.6 \mathrm{~cm}$, remain in the pouch for about 12 to 20 days (Silveira \& Fontoura 2010), with an average incubation time of 16 days, or 0.04 years $\left(t_{0}=-0.04\right)$.

For spatial distribution analyses, the areas and sampling sites for fish habitat characterization were georeferenced and plotted on Google Maps.

\section{Results}

\section{Abundance}

A total of 425 observations were made, including counts and recounts, of which 232 were marked. With the gradual increase in the number of fish collected, and increase in the number of new markings, the proportion of new individuals collected relative to recaptured individuals, tended to gradually decrease. After the sixth sampling, the proportion between new individuals and individuals already marked was relatively balanced, remaining very similar in almost all of the following samplings, with recaptured fish representing on average $44.6 \%$ of the total observations (Figure 4 ).

From the analysis of the Capture Calendar, the site with the highest occurrence of $H$. reidi specimens was the Baleia Stream, presenting an estimated density of about 294 specimens. For Viral, it was obtained

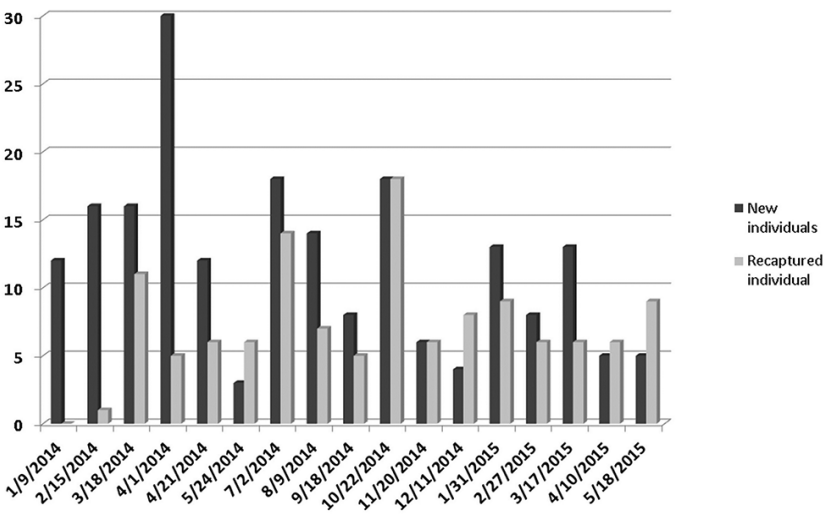

Figure 4. Capture and recaptured longsnout seahorse individuals caught by month from September 2014 to May 2015 in the Vaza-Barris estuary.

an estimate of $69 \mathrm{H}$. reidi, while for Caruara, the total population density estimate was 65 specimens. Thus, it is estimated that the three sampling areas should house approximately 430 individuals of longsnout seahorses. Therefore, it is estimated that $55 \%$ of the seahorse population was marked during this study.

The density of $H$. reidi at the Viral stream ranged from 0 to $0.32 \mathrm{fish} /$ $\mathrm{m}^{2}$; with an average of $0.113 \mathrm{fish} / \mathrm{m}^{2}( \pm 0.088)$. At the Caruara stream, density ranged from 0 to $0.095 \mathrm{fish} / \mathrm{m}^{2}$, with an average of $0.035 \mathrm{fish} /$ $\mathrm{m}^{2}$ ( \pm 0.034$)$. At the Riacho da Baleia stream, density ranged from 0 to 0.233 ind.$/ \mathrm{m}^{2}$, with an average of $0.103 \mathrm{fish} / \mathrm{m}^{2}( \pm 0.066)$.

\section{Height and sex}

In total, 251 fish were males, 195 were females, and 27 were very young individuals considered of undetermined sex. Of these, 279 (135 males, 123 females, and 21 undetermined) were found in the Baleia Stream, 105 (64 males, 38 females, and 3 undetermined) in the Viral Stream, and 89 ( 52 males, 34 females, and 3 undetermined) were found in the Caruara Stream. The samplings with the highest number of observations were October 2013 (53 individuals), September 2013 (45 individuals), April 2014 (35 individuals), and July 2014 (32 individuals).

Measurements on total fish height varied from $2.1 \mathrm{~cm}$ to $19.2 \mathrm{~cm}$, with a mean $14.4 \pm 2.6 \mathrm{~cm}$. The mean size of the females and males was very close ( $14.5 \mathrm{~cm}$ and $15 \mathrm{~cm}$, respectively), and the largest difference was observed in the smallest individuals ( $7 \mathrm{~cm}$ and $10.2 \mathrm{~cm}$, respectively, Table 1).

Table 1. Total number of captured fish (n), mean, minimum (Min), and maximum (Max) total length $(\mathrm{cm})$ by sex of the longsnout seahorse Hippocampus reidi in the Vaza-Barris estuary.

\begin{tabular}{lcccc}
\hline Sex & $\mathbf{n}$ & Mean & Min & Max \\
\hline Undetermined & 27 & $6.9 \pm 2.4$ & 2.1 & 10.1 \\
Females & 195 & $14.5 \pm 1.9$ & 7 & 19 \\
Males & 251 & $15 \pm 1.8$ & 10.2 & 19.2 \\
\hline
\end{tabular}

\section{Habitat use}

Regarding the 425 fish observed, 64\% of individuals were found alone, $25 \%$ of individuals were found in pairs, and $11 \%$ were found in groups of three or more individuals. Most observations (94\%), of the longsnout seahorses were standing or attached to some substrate, while 
only $6 \%$ were swimming. Of those found standing, almost $90 \%$ were attached to roots of $R$. mangle, while $10 \%$ were attached to branches of mangrove trees $(6 \%)$, oysters $(1 \%)$, or supported on the mud in the margins (4\%).

\section{Reproduction}

For $85 \%$ ot individuals it was not possible to define the stage of the reproductive cycle when observed, while $7.4 \%$ were mature females, $7 \%$ were males at an advanced stage of incubation, and $0.6 \%$ were males that had recently released the brood, with one of these males being observed at the final moment of release of the brood. Mature individuals were found in almost all sampling months, with reproduction peaks occurring in February, July, and December 2014, when the proportions between fish in reproductive activity/total catch remained above $30 \%$, while in the other months this ratio averaged $12 \%$. In the months of November 2013 , March and April 2015, no $H$. reidi were observed in reproduction activity.

Throughout the sampling period, the overall sex ratio (M:F) was 1.3. Regarding the sampling sites, the ratio was 1.7 in Viral, 1.5 in Caruara, and 1.1 in the Baleia Stream.

\section{Growth patterns}

The VGBM parameters obtained for 42 individuals (sex combined) were $\mathrm{K}=0.78431$ and $\mathrm{L}_{\infty}=20.21 \mathrm{~cm}$. It is possible to observe in the curve that the largest individuals observed are $\sim 48$ months of age (Figure 5). The smallest individuals observed in reproduction were a $12 \mathrm{~cm}$ male and a female of $13.1 \mathrm{~cm}$, indicating that in the study area the species starts to reproduce only after 15 months of age. The Von Bertalanffy growth curve (Figure 5) shows a more pronounced growth of the monitored seahorses during the first months of life, until about 17 months, and more stability after $16 \mathrm{~cm}$ and 27 months of age.

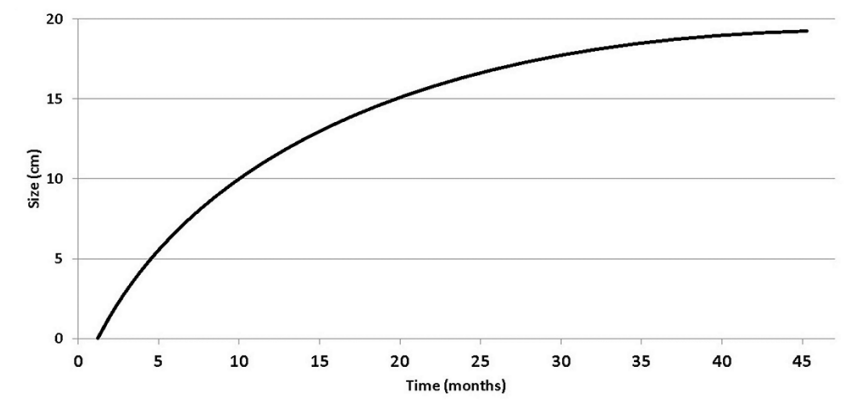

Figure 5. Von Bertalanffy growth model appied to Hippocampus reidi (sex combined) in the Vaza-Barris estuary.

\section{Structured Social Behavior}

From the beginning of the markings, in January 2014, 26 pairs of males and females, 11 pairs of males, three pairs of females, two pairs of males with juvenile individuals, and nine groups with three or more seahorses were observed together. Among the couples found together, eight were in the hatching period (full pouch) when observed. Over time, five couples, two pairs of males with juveniles, and a pair of males stayed together. The information on the recaptures of couples and other groups during the sampling period is illustrated in Figure 6. The observed couples that remained together the most were those formed by individuals 131 and 138, found in October 2014 and later on May 2015, and individuals 3 and 4, found together in January and July 2014.

Once the recaptures of grouped individuals were observed, whether couples or distinct groups, the joint displacement of these individuals was monitored over time, by georeferencing the recaptures. The displacement patterns of couples 17 and 54, 31 and 108, and pair 4 and 42 are described below. The pair of males represented by individuals I4 and I42 in the Baleia Stream, moved together a distance of $150 \mathrm{~m}$ from April to July 2014 (from $11^{\circ} 07^{\prime} 05.0^{\prime \prime} \mathrm{S} 37^{\circ} 09^{\prime} 12.2^{\prime \prime} \mathrm{W}$ to $\left.11^{\circ} 07^{\prime} 14.8^{\prime \prime} \mathrm{S} 37^{\circ} 10^{\prime} 20^{\prime \prime} \mathrm{W}\right)$. The pair formed by individuals 17 and 54, resident in the Baleia Stream, moved together between April and July 2014 a distance of $11 \mathrm{~m}$ (from $11^{\circ} 07^{\prime} 23.4^{\prime \prime}$ $\mathrm{S}, 37^{\circ} 10^{\prime} 21.4^{\prime \prime} \mathrm{W}$ to $11^{\circ} 07^{\prime} 23.0^{\prime \prime} \mathrm{S}, 37^{\circ} 10^{\prime} 21.7^{\prime \prime} \mathrm{W}$ ) and was recaptured (together) in August 2014, about $10 \mathrm{~m}$ away from the site of its previous capture (at $11^{\circ} 07^{\prime} 23.3^{\prime \prime} \mathrm{S}, 37^{\circ} 10^{\prime} 21.8^{\prime \prime} \mathrm{W}$ ). In turn, the couple formed by individuals I31 and I108, also resident in the Baleia Stream, moved together a distance of $65 \mathrm{~m}$ during the period from October 2014 to January 2015 (from $11^{\circ} 07^{\prime} 23.1^{\prime}$ S, $37^{\circ} 10^{\prime} 21.7^{\prime \prime} \mathrm{W}$ to $11^{\circ} 07^{\prime} 21.3$ ” S, 37 $10^{\prime} 20.2^{\prime}$ W), when it was recaptured.

\section{Long Term Movement}

All fish remained in the areas where they were first caught, which indicates that they did not change streams. The monitored fish were found between 0 and $290 \mathrm{~m}$ away from the first capture site, with an average displacement of $49 \mathrm{~m}$. In general it was observed that short displacements occurred between two or more observations. More than $55 \%$ of the recaptured fish had displacements of less than 15 meters between two or more collections. Considering the accuracy of the GPS equipment, it is possible to infer that these fish made small displacements or have not moved between capture events (Figure 7). A fish was initially recaptured 237 meters away from the point of first capture and later recaptured 5 meters away from it. This indicates a initial distance and a later return to the original site (Fish 28, Figure 7).

\section{Discussion}

The present study makes a broad ecological characterization of H. reidi in the Vaza-Barris estuary and provides concrete behavioral ecological information based on the mark-recapture method. In relation to the maximum total length of the species, Mai \& Rosa (2009), studying these fish in the Camurupim/Cardoso and Timonha/Ubatuba estuaries, state of Piauí, NE Brazil indicated that the total height for the species is $20 \mathrm{~cm}$, a value very close to the estimation $\left(\mathrm{L}_{\infty}\right)$ in hereby study $(20.21 \mathrm{~cm})$. The mean size of the females and males had the largest difference in the smallest individuals. This result is probably related to the late development of the brood pouch and the identification of male individuals in the juvenile phase being more difficult than females, which results in several male juveniles being classified as undetermined sex.

Rosa et al. (2007), using underwater visual sighting data (50 x $2 \mathrm{~m}$ transect) gathered along the NE, SE and S portions of the Brazilian coast indicated that individuals of this species are usually found allone or in small groups of up to seven individuals, as also observed herein. The reproduction of the species occurred throughout the year, with breeding peaks occurring in February, July, and October 2014. This result is similar to that published by Rosa et al. (2007), who identified reproductive peaks from October to February along the Brazilian coast. 
Schwarz Junior. et al.

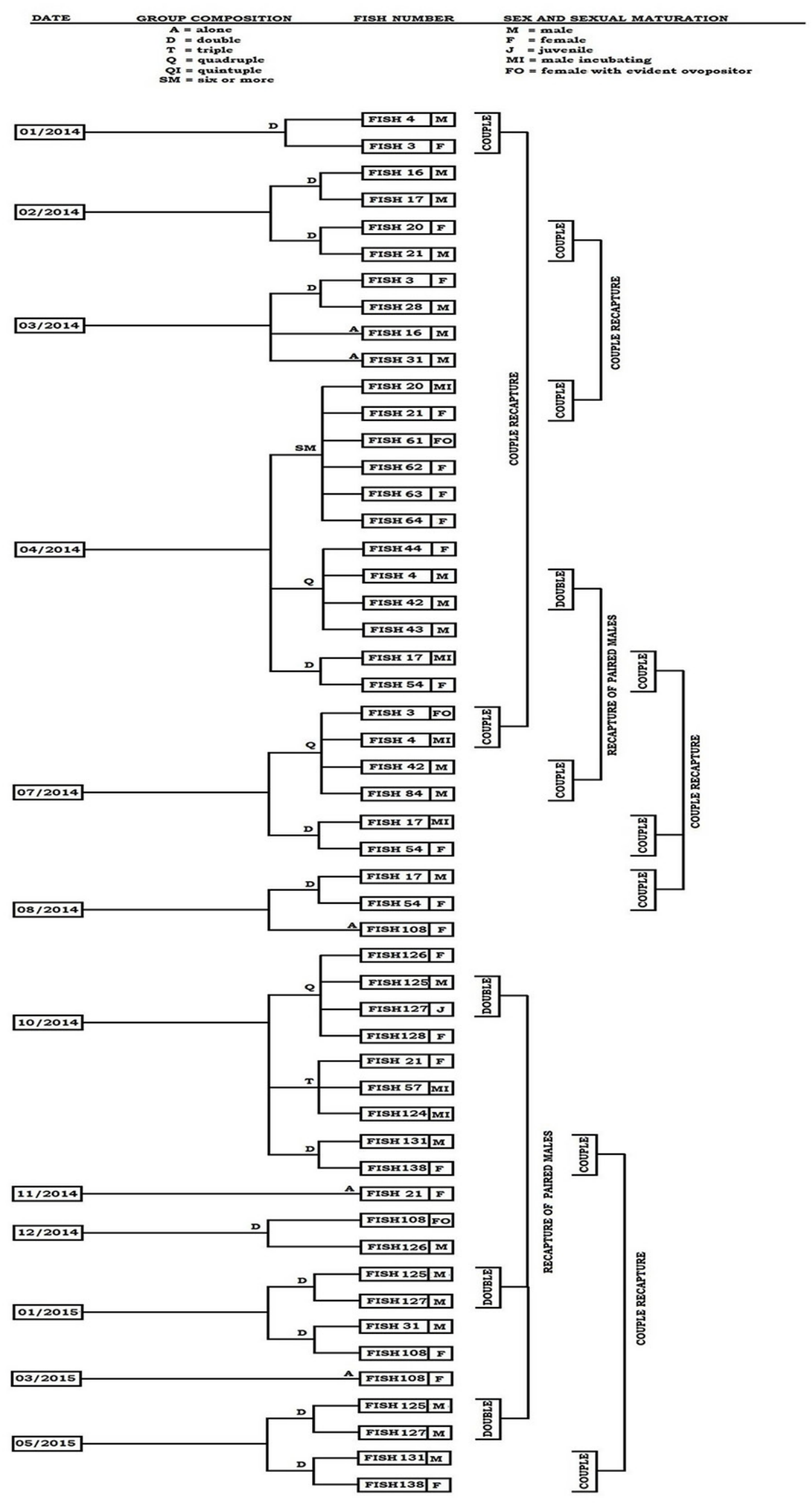

Figure 6. Recaptures of couples and other groups during the sampling period. 


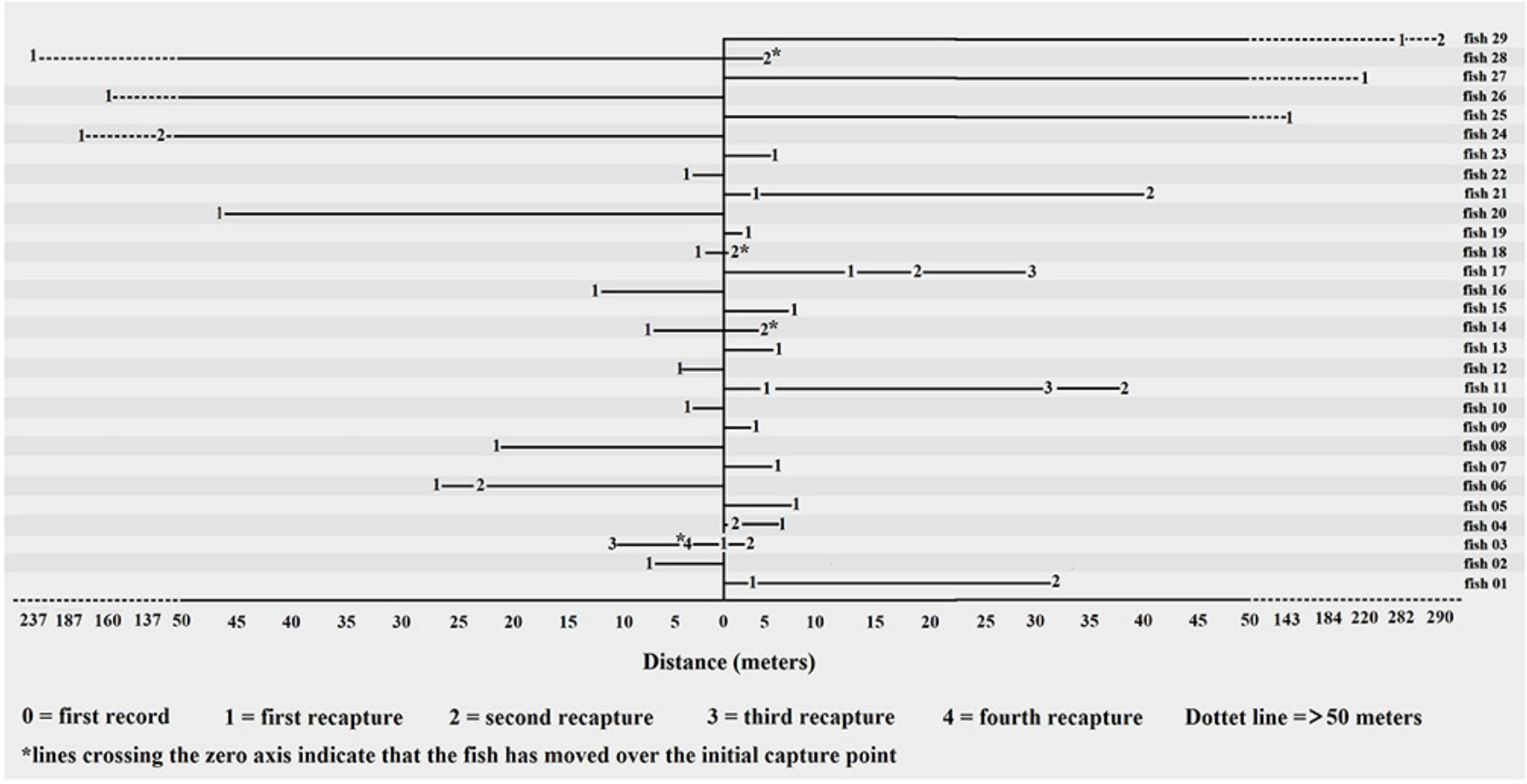

Figure 7. Displacement pattern of H. reidi between capture events.

In the present study, few juvenile individuals were collected (less than $6 \%$ of total). This low catch of juveniles is probably explained by some hypotheses related to the sampling method and the species ecology, namely the difficulty of visualizing the smaller fish during the collection procedure, and the fact that seahorses at the initial stages of development have a planktonic life habit, not yet grasping the roots of the mangrove or other substrates analyzed. Also the young stages may be occupying another habitat of the mangrove ecosystem as a way of avoiding direct competition with the adults of the species. Onthogenetic differences in the use of habitat were demonstrated by Morgan \& Vincent (2007) for the tropical tiger tail seahorrse in a coral reef eocosystem and also by Harasti et al. (2014) for the species Hippocampus whitei in Port Stephens, New South Wales, Australia. Therefore, it is important that future biological and ecological studies investigate the early stages of development.

Regarding the growth pattern, it was observed that the younger individuals show higher growth rates, and that, as expected, this rate slows with aging. The growth constant in this study $(\mathrm{K}=0.784310)$ presented a lower value for this species than previous studies in northeastern Brazil ( $\mathrm{K}=1.195$; Mai \& Velasco 2012) most likely because few juveniles were sampled in the present study. Considering the relationship between growth and life expectancy, it is possible to infer from the VBGC, that individuals from the monitored population live on average 48 months, a longevity much longer than the 30 months pointed out by Mai \& Rosa (2009). It is worth mentioning that the low frequency of capture and also the low number of young individuals in this study influenced the growth parameter of the curve.

The average height at first maturity of $H$. reidi in natural environments was estimated to be between $10 \mathrm{~cm}$ (Mai \& Velasco 2012) and $12.3 \mathrm{~cm}$ (Silveira 2005) in northeastern Brazil, while the average height at first maturity was estimated at $12.4 \mathrm{~cm}$ (Mai 2008). In the present study, the smallest individuals observed in reproduction were a male of $12 \mathrm{~cm}$ and a female of $13.1 \mathrm{~cm}$. Considering these sizes, and considering the projection of VBGC, it is possible to infer that $H$. reidi reproduces in the studied area only after 15 months of life.

The distribution of individuals in the environment was analyzed through the fish marking and monitoring performed in this study. No $H$. reidi moved between any of the three streams, with tagged fish being resighted only at the site at which they were initially tagged. So, recapture data indicate that the population of seahorses in the area is resident and present fidelity to the habitat what corroborate the published literature on issues related to the theme for $H$. reidi and other seahorse species (Moreau \& Vincent 2004, Curtis \& Vincent 2006, Rosa 2007, Caldwell \& Vincent 2013, Gristina et al. 2014, Harasti et al. 2014). However, some fish were found far from the initial observation site. This pattern of movement probably occurred owing to tidal currents, which are used by seahorses for their movement.

In an experiment that analyzed the displacement of $H$. guttulattus, it was possible to identify that marked individuals were able to travel great distances in a short period of time ( $150 \mathrm{~m}$ in 8 days) with a single animal moving $60 \mathrm{~m}$ in a single day (Caldwell \& Vincent, 2013). Although this study indicates that $H$. reidi are closely associated with the monitored sites, individual fish can still move great distances, as shown by a seahorse that moved $273 \mathrm{~m}$ and then returned to his previous home range centers. Harasti et al. (2014) demonstrated that even though some individual $H$. whitei were observed moving around their site, they displayed strong site fidelity, as evident through repeated observations of the same individuals existing at the same sites and even on the same holdfasts for long durations in this study. Small displacements were also significantly observed through the recaptures in this study, with more than $55 \%$ of the recaptured fish moving less than 15 meters between recaptures.

It must be considered that, according to Acosta \& Toloza (2012), a standard market receiver GPS has an accuracy of 10-15 meters, in 
$95 \%$ of times. In order to achieve a sub-metric level of precision, to more accurately recognize movement patterns, it is necessary to apply additional techniques.

The data related to the grouping of seahorses indicates that there is fidelity to the partner, as previously mentioned by other authors (Lourie et al. 1999, Mai \& Rosa 2009). Moreover, the pairs of males, females, and adults with juveniles found together exemplify the highly structured social behavior of seahorses, as previously reported in the literature (Vincent \& Sadler 1995, Rosa et al. 2007). In this study it was observed a predominance of pairs of individuals, with higher occurrences of couples, pairs of males and pairs of females, respectively. The same observation was made by Perante et al. (2002) when analyzing social associations of Hippocampus comes in the central Phillipines, where seahorses were most commonly sighted in pairs $(60 \%$ of 516 observations). These autors considered that the higher number of sightings per pair-wise combination of seahorses suggested that these were probably more stable than the quartets. They demonstrated that social groups of more than two animals were fluid: one often sighted trio evolved after 4 weeks into a quartet of two males and two females, and one set of trio sightings represented a quartet which one individual was sometimes missing (Perante et al 2002).

By exhibiting a patchy distribution pattern, Hippocampus species tends to present low population densities (Lourie et al. 2004, Foster \& Vincent 2004, Siqueira et al. 2017). Rosa et al. (2007) point out that the population densities registered for $H$. reidi in Brazil vary from 0.0023 to 0.066 fishes $/ \mathrm{m}^{2}$. On the coast of Piauí, in the Camurupim Cardoso estuary, a high population density $\left(0.04\right.$ fishes $/ \mathrm{m}^{2}$ ) was recorded (Mai \& Rosa 2009). Freret-Meurer \& Andreata (2008), at Araçatiba beach, Rio de Janeiro, found an average density of $0.18 \pm 0.089$ fishes $/ \mathrm{m}^{2}$, ranging from 0 to $0.4 \mathrm{~m}^{2}$.

Our findings, especially in the Viral and Baleia streams, show that $H$. reidi densities are almost twice bigger tham those observed in other studies performed in tropical northeast of the Brazilian coast, where densities are usually higher than of subtropical populations near the southern limit of distribution of this species (Siqueira et al. 2017). This demonstrate the importance of the study area for the conservation of the species.

The biocompatible elastomer implant marking tool proved to be an efficient method for Capture-Mark-Recapture (CMR) studies, allowing greater reliability in the evaluation of population size estimation data when compared to probabilistic estimators applied to punctual capture data. The use of a marking method capable of providing reliable responses to fish population studies is currently a major challenge for researchers around the world, especially considering the nektonic character of fish, which results in a large capacity for displacement and distribution. An increasing literature documents the utility of VIE in very small aquatic animals, like fish and invertebrates (Godin et al. 1996, Frederick 1997, Malone et al. 1999, Brennan et al. 2005, Curtis 2006, Imbert et al. 2007).

\section{Acknowledgments}

This study was possible thanks to the financial support of the Boticário Group Foundation for Nature Protection and the Foundation for Research and Technological Innovation of the State of Sergipe FAPITEC. We thank the project team: Curega, fisherman and guide; Crislayne de Souza Bery; Márcia Almeida Valença Porto; Camilo
Emmanuel Viana Amor Divino; Priscila Monise; Analee Alves; Rosualdo Conceição Vieira; and Daniel Masato Vital Hide.

\section{Authors' Contributions}

Roberto Schwarz Junior: Substantial contribution in the concept and design of the study; Contribution to data collection; Contribution to data analysis and interpretation; Contribution to manuscript preparation.

Ana Cristina Novelino Penna Franco: Contribution to data analysis and interpretation; Contribution to manuscript preparation.

Adauto de Souza Ribeiro: Contribution to data collection.

Marcel Andrade Martins: Contribution to data collection.

Marcelo Soeth: Contribution to manuscript preparation; Contribution to critical revision, adding intelectual content.

Olímpio Rafael Cardoso: Contribution to manuscript preparation; Contribution to critical revision, adding intelectual content.

Henry Louis Spach: Contribution to manuscript preparation; Contribution to critical revision, adding intelectual content.

\section{Conflicts of Interest}

We reiterate have no conflicts of interest to disclose.

\section{References}

ACOSTA; N. \& TOLOZA, J. 2012. Techniques to improve the GPS precision. (IJACSA). 3(8): 125-130.

BRENNAN, N.P., LEBER, K.M., LEE BLANKENSHIP, H., RANSIER, J.M. \& DEBRULER, R.JR. 2005. An evaluation of coded wire and elastomer tag performance in juvenile common snook under field and laboratory conditions. N. Am. J. Fish. Manage. 25(2):437- 445.

BROWER, J.E. \& ZAR, J.H. 1984. Field \& laboratory methods for general ecology. 2 ed. Iowa State, William Company Brown Publishers.

CURTIS, J.M.R. 2006. Visible implant elastomer color determination, tag visibility, and tag loss: potential sources of error for mark-recapture studies. N. Am. J. Fish. Manage. 26(2):327- 337.

CALDWELL, I. \& VINCENT, A.J. 2013. A sedentary fish on the move: effects of displacementon long-snouted seahorse (Hippocampus guttulatus Cuvier) movement and habitat use. Environ. Biol. Fish. 96:67-75.

CURTIS, J.M.R., SANTOS, S.V., NADEAU, J.L., GUNN, B., BIGNEY WILNER, K., BALASUBRAMANIAN, H., OVERINGTON, S., LESAGE, C.M., D'ENTREMONT, J. \& WIECKOWSKI, K. 2017. Life History and Ecology of the Elusive European Short-Snouted Seahorse Hippocampus hippocampus. J. Fish Biol. 91(6):1603-1622.

FOSTER, S. \& VINCENT, A.C.J. 2004. The life history and ecology of seahorses, Hippocampus spp.: implications for conservation and management. J. Fish Biol. 65(1):1-61.

FREDERICK, J. L. 1997. Evaluation of fluorescent elastomer injection as a method for marking small fish. B. Mar. Sci. 61(2):399-408.

GODIN, D.M., CARR, W.H., HAGINO, G., SEGURA, F., SWEENEY, J.N. \& BLANKENSHIP, L. 1996. Evaluation of a fluorescent elastomer internal tag in juvenile and adult shrimp Penaeus vannamei. Aquaculture 139(34):243-248.

GRISTINA, M., CARDONE, F., CARLUCCI, R., CASTELlANO, L., PASSARELLI, S. \& CORRIERO, G. 2014. Abundance, distribution and habitat preference of Hippocampus guttulatus and Hippocampus hippocampus in a semienclosed central Mediterranean marine area. Mar. Ecol. 36(1): 57-66.

HARASTI, D., MARTIN-SMITH, K. \& GLADSTONE, W. 2012. Population dynamics and life history of a geographically restricted seahorse, Hippocampus whitei. J. Fish Biol. 81(4):1297-1314. 
HARASTI, D., MARTIN-SMITH, K. \& GLADSTONE, W. 2014. Ontogenetic and sex-based differences in habitat preferences and site fidelity of White's seahorse Hippocampus whitei. J. Fish Biol. 85(5):1413-1428.

HUGHES, A.R., WILliams, S.L., DUARTE, C.M., HECK, K.L. \& WAYCOTT, M. 2009. Associations of Concern: Declining Seagrasses and Threatened Dependent Species. Front. Ecol. Environ. 7(5):242-246.

IMBERT, H., BEAULATON, L., RIGAUD, C. \& ELIE, P., 2007. Evaluation of visible implant elastomer as a method for tagging small European eels. J. Fish Biol. 7(5):1546-1554.

KREBS, C.J. 1996. Demographic changes in fluctuating of Microtus californicus. Ecol. Monogr. 36(3):239-73.

LE CHEMINANT, J. 2000. An investigation to establish the suitability of Opalithplattchen (Bee Tag), Fly and Visible Implant Fluorescent Elastomer (VIFE) tagging systems for marking the Knysna seahorse, Hippocampus capensis. M.Sc. thesis, Bournemouth University, United Kingdom.

LIMA, J. S. G. \& SILVA, C. A. 2014. Carcinicultura marinha familiar no estuário do Rio Vaza-Barris, Sergipe: implicações para uma produção sustentável. Brasília, Embrapa.

LOTZE, H.K., LENIHAN, H.S., BOURQUE, B.J., BRADBURY, R.H., COOKE, R.G., KAY, M.C., KIDWELL, S.M., KIRBY, M.X., PETERSON, C.H. \& JACKSON, J.B.C. 2006. Depletion, Degradation, and Recovery Potential of Estuaries and Coastal Seas. Science. 312(5781):1806-1809.

LOURIE, S.A.; VINCENT, A.C.J. \& HALL, H.J. 1999. Seahorses: an identification guide to the world's species and their conservation. London, Project Seahorse.

LOURIE, S.A., FOSTER, S.J., COOPER, E.W.T. \& VINCENT, A.C.J. 2004. A Guide to the Identification of Seahorses. Project Seahorse and Traffic North America. Washington D.C, University of British Columbia and World Wildlife Fund.

MAI, A.C.G. 2008. Estrutura populacional e história de vida de Hippocampus reidi Ginsburg, 1933 (Teleostei, Syngnathidae) no Litoral do Piauí, Brasil. João Pessoa. Dissertação de mestrado, Universidade Federal da Paraíba, João Pessoa.

MAI,A.C.G. \& ROSA, I.M.L. 2009. Aspectos ecológicos do cavalo-marinho Hippocampus reidi no estuário Camurupim/Cardoso, Piauí, Brasil, fornecendo subsídios para a criação de uma Área de Proteção Integral. Biota Neotrop. 9(3): 85-91. http://dx.doi. org $10.1590 /$ S1676-06032009000300007 (last access on 04/06/2020)

MAI, A.C.G. \& VELASCO, G. 2012. Population dynamics and reproduction of wild longsnout seahorse Hippocampus reidi. J. Mar. Biol. Assoc. UK. 92(2):421-427.

MALONE, J.C., FORRESTER, G.E. \& STEELE, M.A. 1999. Effects of subcutaneous microtags on the growth, survival, and vulnerability to predation of small reef fishes. J. Exp. Mar. Biol. Ecol. 237(2):243-253.

MOREAU, M.A. \& VINCENT, A.C.J. 2004. Social structure and space use in a wild population ofthe Australian short-headed seahorse Hippocampus breviceps (Peters, 1869). Mar. Freshwater Res. 55(3): 231-239.

MORGAN, S. K. \& VINCENT, A. C. J. 2007. The ontogeny of habitat associations in the tropical tiger tail seahorse Hippocampus comes Cantor, 1850. Journal of Fish Biology. 71(3):701-724.
MUNRO, J.L. 1982. Estimation of the parameters of the von Bertalanffy growth equation from recapture data at variable time intervals. Ices. J. Mar. Sci. 40(2):199-200.

OLIVEIRA, T. \& POLLOM, R. 2017. Hippocampus reidi. The IUCN Red List of Threatened Species 2017:e.T10082A17025021. http://dx.doi.org/10.2305/ IUCN.UK.20173.RLTS.T10082A17025021.en Downloaded on 20 Dec 2019.

PERANTE, N.C., PAJARO, M.G., MEEUWIG, J.J. \& VINCENT, A.C.J. 2002. Biology of a seahorse species Hippocampus comes in the central Philippines. J. Fish Biol. 60(4):821-837.

ROSA, I.M.L.; OLIVEIRA, T.P.R.; CASTRO, A.L.C.; MORAES, L.E.S.; XAVIER, J.H.A.; NOTTINGHAM, M.C.; DIAS, T.L.P.; BRUTO-COSTA, L.V.; ARAÚJO, M.E.; BIROLO,A.B.; MAI,A.C.G. \& MONTEIRO-NETO, C. 2007. Population characteristics, space use and habitat associations of the seahorse Hippocampus reidi Ginsburg, 1933. Neotrop. Ichthyol. 5(3):405-414.

ROSE, E., SIMMONDS, M., HAYASHIDA-BOYLES, A. L. \& MASONJONES, H. D. 2019. Seasonal and Spatial Variation in the Reproductive Biology of the Dwarf Seahorse Hippocampus Zosterae. J. Fish Biol. 95(2):357-366.

SILVEIRA, R.B. 2005. Dinâmica populacional do cavalo-marinho Hippocampus reidi no manguezal de Maracaípe, Ipojuca, Pernambuco, Brasil. Tese de doutorado, Pontifícia Universidade Católica do Rio Grande do Sul. Porto Alegre.

SILVEIRA, R.B. \& FONTOURA, N.F. 2010. Fecundity and fertility of the longsnout seahorse, Hippocampus reidi (Teleostei: Syngnathidae), in tropical Brazil. Braz. J. Biosci. 8(4):362-367.

SIQUEIRA, A.C., QUIMBAYO, J.P., CANTOR, M., SILVEIRA, R.B. \& DAURA-JORGE, F.G. 2017. Estimating Population Parameters of Longsnout Seahorses, Hippocampus Reidi (Teleostei: Syngnathidae) through Mark-Recapture. Neotrop. Ichthyol. 15(4):1-8.

TAYLOR, C.C. 1958. Cod growth and temperature. Ices. J. Mar. Sci. 23(3):366-370.

VASCO, A.N., MELLO JÚNIOR, A.V., SANTOS, A.C.A.S., RIBEIRO, D.O., TAVARES, E.D. \& NOGUEIRA, L.C. 2010. Qualidade Da Água Que Entra No Estuário Do Rio Vaza Barris Pelo Principal Fluxo de Contribuição de Água Doce. Sci. Plena. 6(9):1-10.

VINCENT, A.C.J. \& SADLER, L.M. 1995. Faithful pair bonds in wild seahorses, Hippocampus whitei. Anim. Behav. 50(6):1557-1569.

WOODS, C.M.C. \& MARTIN-SMITH, K.M. 2004. Visible implant fluorescent elastomer taggingof the big-bellied seahorse, Hippocampus abdominalis. Fish. Res. 66(2-3):363-371.

WORM, B., BARBIER, E.B., BEAUMONT, N., DUFFY, J.E., FOLKE, C., HALPERN, B.S., JACKSON, J.B. C., LOTZE, H.K., MICHELI, F. \& PALUMBI, S.R. 2006. Impacts of Biodiversity Loss on Ocean Ecosystem Services. Science. 314(5800):787-790.

Received: 01/10/2020

Revised: 25/02/2021

Accepted: 03/03/2021

Published online: 23/04/2021 